\title{
Tobacco as Potential Food Source and Smoke Material*
}

\author{
by T.C.Tso \\ Beltsville Agricultural Researdh Center, Agricultural Research Service, \\ U.S. Department of Agriculture, Beltsville, Maryland, U.S.A.
}

\section{Introduction}

In $1611 \mathrm{John}$ Rolfe obtained from Trinidad and Venezuela the first Nicotiana seeds to be planted in North America. The tobacco plants were gradually extended from Virginia to all parts of the world. For more than 300 years the tobacco industry has been conservative, traditional, and slow to change until the last 10 to 15 years. Many reasons make such changes necessary, the two main ones being the high cost of production, including the extensive use of energy, and the demand for better quality and usability of leaf tobacco, including the smoking and health problem.

\section{Year 1975 - Status of Tobacco Production}

In 1975 approximately 11.4 billion pounds of leaf tobacco were produced throughout the world. Production costs vary from country to country because of the demand for energy varying with locality. Flue-cured tobacco is the highest in energy demand per acre per year in comparison with any other crops. For example, in the United States, 20.8 barrels of oil equivalent is needed to produce one acre of tobacco per year in comparison with tomato, 18.4; lettuce, 15.0; potato, 9.6; rice, 8.2 ; corn silage, 4.1 ; soybean, 2.0 ; and wheat, 0.6 barrels of oil per acre per year (1). Improvement in production efficiency has resulted in this high demand for energy. Thirty years ago approximately 2 million acres of land was used for tobacco production in the United States, but in 1975 there was only 950,000 acres of land used for tobacco production. The total yield 30 years ago in the USA was 2.3 billion pounds, but in 1975 it was 1.9 billion pounds of tobacco. Along with the $50 \%$ reduction of land usage, there was almost a $100 \%$ increase in yield per acre. As a result, the total tobacco production remained at approximately the same level. This was made possible because of efficient usage of fertilizer, irrigation, crop protection, mechanization, and other means. All of these production inputs require energy. The increase in demand for energy makes it necessary either to find a heaper source of energy, or to make more efficient usage of the tobacco product.

\footnotetext{
- Presented at the Siztb International Tobacco Scienti6e Congress (Coresta) held in Tokyo, Japan, in November 1976.
}

In considering other sources of energy, one generally refers to the physical means of collecting and utilizing solar energy. Obviously we are still a long way off in achieving this purpose. The total utilization of energy on earth by human from the solar source is relatively small (2). According to the world average we use only about $50 \mathrm{ppm}$ of available solar energy that falls on the earth's surface. In the United States the utilization is much higher, but still only about $1 / 10$ of one percent of solar energy is being used. Scientists estimate that under favorable conditions of photosynthesis $3 \%$ of the solar energy can be fixed in biomass. The biomass production currently is about 100 billion tons of dry weight, but most of it is not effectively utilized (2). For example, better use of many tobacco components or other energy products could be made than is being done at the present time. Generally, one kilo-calorie (kcal) of energy enters the plant through a photosynthetic system representing approximately 0.26 grams of mass as glucose, but only about 0.12 grams of mass as amino acids. However, most of this mass is wasted in combustion. Scientists must find means to increase the photosynthetic efficiency, and to make more effective use of synthetic products from plants.

\section{How to Make Better Use of All Tobacco Products}

As far as tobacco smoking is concerned, the components of leaf tobacco can be divided into three groups. The first group includes components which are desirable for organoleptic and physiological daracteristics which are the most important in so far as smoke quality and tobacco usability are concerned. In the second group, the components include "neutral" materials which do not play any significant role in affecting the quality of tobacco smoke. The third group of components contribute, generally, to the undesirable effects of smoke. Both the second and third groups of compounds are "wasted" during combustion and some of these materials are beneficially usable. One of the compounds in the third group is Fraction I protein. Several other compounds can also be obtained from leaf tobacco for beneficial usage. For example, excess nicotine and other alkaloids removed from tobacco can be used for pesticides. Rutin can be used for medicinal purposes. Protein fraction 
does not contribute in any significant way to smoke aroma or flavor, but does contribute to the formation of $\mathrm{HCN}$ and other undesirable nitrogenous constituents in smoke. If Fraction I protein can be removed from tobacco before combustion, two purposes can be achieved: leaf quality and usability can be improved, and Fraction I protein can be used for human food and/or animal feeds.

\section{The Nature of Fraction I Protein}

Fraction I protein is the major soluble protein of green plants. Very frequently $50 \%$ of the soluble and $25 \%$ of the total leaf protein is Fraction I protein. It is the most abundant protein as it is the enzyme that catalyzed the first step in the transformation of $\mathrm{CO}_{2}$ into carbohydrates during photosynthesis. In many crops this Fraction I protein has been extensively studied, including spinach, wheat, rice, cabbage, clover, and tobacco. Kawashima and Wildman were the first to crystallize and define the nature of Fraction I protein from tobacco $(3,4)$. The crystal protein from tobacco is pure, tasteless, colorless, and odorless. Although it has been suggested that 100 or more pounds of pure Fraction I protein could be obtained from one acre of tobacco under favorable conditions (5), our conservative estimation is that at least $1-2 \%$ of tobacco weight or 20-40 pounds per acre of Fraction I protein could be obtained at current tobacco yield levels, and could be much higher with increased tobacco yield and improved extraction method. Fraction I protein is composed entirely of amino acids with no carbohydrates or pigments. It has a high molecular weight and possesses a very large unit cell. Most of the space in Fraction I protein crystals is occupied by water. This property of the protein to organize water suggests that it can be manufactured in a tasteless gel-like material such as soybean curd which is popularly used as food in many countries.

Table 1. Comparison of essential amino acids in Fraction I proteln, FAO provlsional pattern, and other sources (g/100 g proteln).

\begin{tabular}{|c|c|c|c|c|c|c|}
\hline & $\begin{array}{l}\text { Frac- } \\
\text { tion I } \\
\text { pro- } \\
\text { tein* }\end{array}$ & $\begin{array}{l}\text { FAO } \\
\text { provi- } \\
\text { sional } \\
\text { pat- } \\
\text { tern }\end{array}$ & $\mathrm{Egg}^{* \star}$ & $\begin{array}{l}\text { Mil } \\
\text { Hu- } \\
\text { man }\end{array}$ & Cow & $\begin{array}{l}\text { Soy- } \\
\text { bean*** }\end{array}$ \\
\hline Isoleucine & 4.2 & 4.2 & 6.8 & 6.4 & 6.4 & 2.1 \\
\hline Leucine & 8.8 & 4.8 & 9.0 & 8.9 & 9.9 & 2.9 \\
\hline Lysine & 5.8 & 4.2 & 6.3 & 6.3 & 7.8 & 2.4 \\
\hline $\begin{array}{l}\text { Phenyl- } \\
\text { alanine }\end{array}$ & 4.4 & 2.8 & 6.0 & 4.6 & 4.9 & 1.9 \\
\hline Tyrosine & 4.9 & 2.8 & 4.4 & 5.5 & 5.1 & 1.2 \\
\hline Methionine & 1.6 & 2.2 & 3.1 & 2.2 & 2.4 & 0.5 \\
\hline Threonine & 5.2 & 2.8 & 5.0 & 4.6 & 4.6 & 1.5 \\
\hline Tryptophan & 1.5 & 1.4 & 1.7 & 1.6 & 1.4 & 0.5 \\
\hline Valine & 7.2 & 4.2 & 7.4 & 6.6 & 6.9 & 2.0 \\
\hline
\end{tabular}

Source:

- Kawashima and Wildman (1971).

* FAO Nutrition Studies, No. 16 (1957).

** USDA Home Econ. Res. Report \# 4 (1957).
The crystallized material is stable and easy to store. Table 1 shows a comparison of essential amino acids from various materials with the provisional pattern of nutrition as provided by the Food and Agriculture Organization (FAO) of the United Nations (6). It is rather clear that Fraction I protein is quite similar to that of the FAO provisional pattern, and its specific nutritional value is comparable with milk and surpasses that of soybeans (7).

\section{Homogenized Leaf Curing}

Conventional tobacco curing processes do not allow any possibility of removing any components such as those mentioned above. The homogenized leaf curing (HLC) procedure does provide an opportunity for changing the chemical and physical properties of the leaf in addition to the saving of labor and time (8). The first stage of HLC involves homogenization or maseration of the harvested leaf material. As long as the leaf mass is in the slurry form, any fractions which are not desirable or wasted in combustion can be easily removed before incubation and dehydration. Based on the Theoretical Model which we proposed recently, leaf quality and usability may be improved by removal of certain components (9). One of these removable components is Fraction I protein. The extraction and purification of Fraction I protein is rather similar to the crystallization of sugar from sugar-cane or sugar-beets, as illustrated in Figure 1, which represents the scheme for the crystallization and purification of Fraction I protein (4). At various steps of this process, other components such as alkaloids, lipids, free amino acids, certain carbohydrates, and phenolic compounds may be separated. Some of these compounds can be removed if so desired and others can be returned to the base slurry material prior to incubation and dehydration. This may enhance quality of HLC material subsequently reconstituted into sheet tobacco for smoking (8).

\section{Potential Use for Fraction I Protein}

Our daily consumption of $2,010 \mathrm{kcal}$ of food from plants requires $1320 \mathrm{kcal}$ to grow, producing a net gain of $690 \mathrm{kcal}$ because the solar energy harvested as food exceeds that needed for production (1). This does not include the $1380 \mathrm{kcal}$ per day of food energy derived from animal sources. The total daily consumption of $3390 \mathrm{kcal}$ is based on North American data, which is much higher than the world average today (1).

Because of the high energy usage for tobacco production, means should be sought to utilize all usable components from the tobacco plant and at the same time to provide a more desirable product for tobacco smoking. In projecting to the year 2000 , one may assume that the per capita diet need will remain at the $3390 \mathrm{kcal}$ level. Current tests showed that close spacing culture can produce $3500 \mathrm{lb}$. or more tobacco per acre. We project the total production of tobacco in 1985 to be 12.5 billion pounds and in the year 2000, 20 billion pounds without any acreage increase. The Fraction I protein 
Flgure 1. Procedure for extraction of Fractlon I protein.

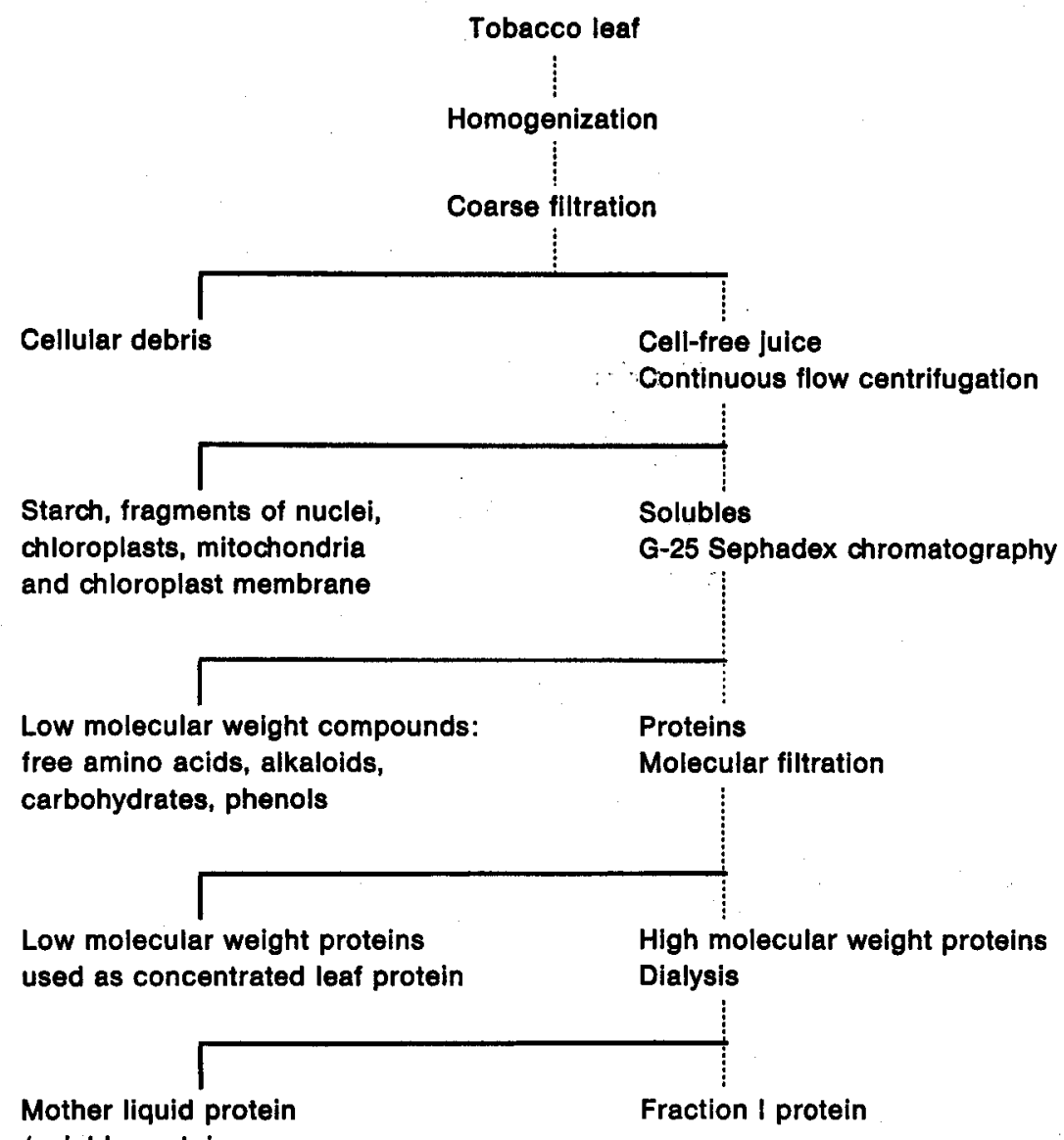

(soluble protein or

Fraction II protein)

(after Kawashima and Wildman, 1971).

extractable from tobacco at years 1985 and 2000 would be approximately 380 and 600 million $\mathrm{lb}$., respectively. In addition, the mixture of other soluble proteins or Fraction II protein amounts to $3-4 \%$ of leaf weight and could be used for human food or animal feed. The Fraction II protein may yield additional 380 and 600 million lb. respectively in years 1985 and 2000. Combining Fraction I and Fraction II proteins, they may provide, in year $2000,1.2$ billion lb. protein which is sufficient to meet the protein need for 33 million people, based on the FAO standard. The usage of a beneficial by-product of tobacco would justify the use of energy for this expensive crop.

\section{Effect on Tobacco Quality and Usability}

The use of homogenized leaf curing has demonstrated drastic changes in tobacco and tobacco smoke, even without the removal of any leaf components (8). The nitrogenous fraction of leaf tobacco is known to be associated with many smoke variables. Table 2 shows correlations among certain nitrogenous fractions in leaf and selected smoke variables. It should be pointed out here that most of these associations are indirect in nature, except that of $\mathrm{HCN}$ and possibly some other nitrogenous constituents which are directly associated with leaf nitrogen. The specific relationship between Fraction I protein and smoke components is not yet available, but is expected to be similar to that of other nitrogenous compounds. Reduction of Fraction I protein and other soluble nitrogenous fractions in the leaf by HLC process may correspondingly reduce the formation of many undesirable constituents in smoke, and thus result in a smoking product of better quality and improved usability.

Table 2. Correlations among certain nitrogenous fractions in leaf and selected smoke varlables.

\begin{tabular}{|c|c|c|c|c|c|c|c|}
\hline \multirow{2}{*}{$\begin{array}{l}\text { Leaf } \\
\text { variables }\end{array}$} & \multicolumn{7}{|c|}{ Smoke variables } \\
\hline & $\begin{array}{l}\text { Dry } \\
\text { TPM }\end{array}$ & $\mathrm{BaP}$ & $\mathrm{BaA}$ & $\mathrm{HCN}$ & $\begin{array}{l}\text { Phe- } \\
\text { nols }\end{array}$ & $\mathrm{CO}$ & $\mathrm{CO}_{2}$ \\
\hline Total N & $.884^{* *}$ & $.793^{* *}$ & $.760^{* *}$ & $.831^{\star \star *}$ & $.949^{* *}$ & $.562^{* *}$ & $.442^{* *}$ \\
\hline $\begin{array}{l}\text { Total vol- } \\
\text { atile bases }\end{array}$ & $.758^{* *}$ & $.672^{* *}$ & $.650^{* *}$ &.$\underline{723}^{\text {*** }}$ & $.864^{* *}$ & $.469^{* *}$ & .304 \\
\hline $\begin{array}{l}\text { Free amino } \\
\text { acids }\end{array}$ & $.555^{* *}$ & $.449^{*}$ & $.427^{\star}$ & $.605^{* *}$ & $.552^{* *}$ & .335 & .453 \\
\hline
\end{tabular}

Underscored data $=\mathrm{R}^{2}$ value close to or higher than 0.5 .

- $5 \%$ significance.

** $1 \%$ signiflcance. 


\section{Looking Toward the Year 2000}

Extensive studies are underway to perfect and simplify the procedures for removal of Fraction I protein during the HIC process (11). The test materials involve several tobacco types. This novel approach would make tobacco an excellent source of food as well as smoking material.

About 35 years ago Albert Einstein asked the question: "Why does the magnificent applied science which saves work and makes life easier bring us so little happiness?". Then he answered the question himself: "Because we have not yet learned to make sensible use of it". We hope that in the year 2000 when we have six billion people to feed, we can make sensible use of Fraction I protein, which otherwise will be literally "going up in smoke". It is indeed a terrible waste of energy and contributes detrimentally to our environment. Some may consider this approads to be foolish in comparison with our current practice of tobacco production. To them we can only quote one of the old Chinese philosophers who said: "We are thankful to those fools, they are the only ones who dare to dream of something new and seemingly impossible ${ }^{\alpha}$.

\section{SUMMARY}

Fraction $I$ protein is the most abundant protein in tobacco and accounts for $50 \%$ of its soluble protein. It is composed entirely of amino acids. Its specific nutritional value, is comparable with milk and surpasses that of soybeans. During tobacco combustion, Fraction I protein may contribute to the formation of $\mathrm{HCN}$ and other undesirable nitrogenous constituents in smoke. It can be removed from harvested leaf tobacco through homogenized leaf curing (HLC) process to improve leaf quality and usability. Considering the total world tobacco production as a whole, Fraction I protein and other soluble proteins so recovered may provide enough food for millions of people. In addition, there will also be a better smoking product.

\section{ZUSAMMENFASSUNG}

Fraktion-I-Protein ist das im Tabak am reichlichsten vorkommende Eiweiß und macht 50\% von dessen löslichem Eiweiß aus. Es besteht nur aus Aminosäuren. Sein spezifischer Nährwert ist dem der Mildh vergleichbar und dem von Sojabohnen überlegen. Während der. Verbrennung des Tabaks kann Fraktion-I-Protein zur Bildung von Cyanwasserstoff (HCN) und anderen unerwilinschten stickstoffhaltigen Raudbestandteilen beitragen. Es kann aus dem geernteten Blattabak zur Verbesserung der Qualität und der Gebrauchseignung des Blattgutes mit Hilfe des HLC-Verfahrens (homogenized leaf curing) entfernt werden. Unter Zugrundelegung der gesamten Tabakerzeugung der Welt kann durch das Fraktion-IProtein und andere auf diese Weise gewonnene lösliche
Proteine genug Nahrung für Millionen von Menschen verfügbar gemadt werden. Darüber hinaus ergibt sich ein besseres Rauchprodukt.

\section{RESUME}

La protéine Fraction I est la proteine la plus abondante dans le tabac, et représente $50 \%$ de ses protéines solubles. Elle est composée entièrement d'acides aminés. Sa valeur spécifique de nutrition est comparable à celle du lait et dépasse celle des germes de soja. Pendant la combustion du tabac, il est possible que la protéine Fraction I contribue a la formation de HCN et d'autres composés azotés indésirables dans la fumée. En vue d'améliorer la qualité et la possibilité d'utilisation du tabac, la protéine Fraction I peut être éliminée des feuilles de tabac récoltées, par le procédé HLC (homogenized leaf curing/séchage de feuilles homogénéisées). En considérant l'ensemble de la production mondiale du tabac, la protéine Fraction I et d'autres protéines solubles ainsi récupérées peuvent produire suffisamment d'aliments pour des millions de personnes. En plus, le produit à fumer sera amélioré.

\section{REFERENCES}

1. Heichel, G. H.: Private communication, and Frontiers of plant science; The Conn. Agr. Exp. Station, Spring Issue, pp. 2-4, 1975.

2. Abelson, Philip H.: Science 191 (1976), \#4233 Editorial.

3. Kawashima, N., and S. G. Wildman: Ann. Rev. Plant Physiol. 21 (1970) 325-358.

4. Kawashima, N., and S. G. Wildman: Biochem. Biophys. Acta 229 (1971) 240-249.

5. Wildman, S. G.: Private communication, 1976.

6. Food Agr. Organ. of the United Nations: FAO Nutr. Studies No. 16, p. 26, 1957.

7. U. S. Dept. Agr. Home Econ. Res. Report \# 4, 1957.

8. Tso, T. C., R. Lowe, and D. W. DeJong: Beitr. Tabakforsduung 8 (1975) 41-51.

9. Tso, T. C., and G. Gori: Beitr. Tabakforschung 8 (1975) 167-173.

10. Chancellor, W. J., and J. R. Goss: Science 192 (1976) 213-218.

11. Collaborative research is in progress in the laboratories of Dr. S. D. Kung, Univ. Md. Baltimore County Campus, and of Dr. D. DeJong, Oxford Tobacco Station, USDA, Oxford, N. C., and of Dr. R. Lowe, University of Kentudky, Lexington, Ky.

\section{The autbor's address:}

Beltsville Agricultural Research Center, Agricultural Research Service, U.S. Dept. of Agriculture, Beltsville, Maryland, 20705, US.A. 